\title{
Drought and Property Prices: Empirical Evidence from Provinces of Iran
}

\author{
Mohammad Reza Farzanegan ${ }^{1}$ (D) $\cdot$ Mehdi Feizi $^{2} \cdot$ Hassan F. Gholipour ${ }^{3}$
}

Received: 28 August 2020 / Accepted: 9 December 2020 / Published online: 28 December 2020

(C) The Author(s) 2020

\begin{abstract}
This study examines the effect of drought on housing and residential land prices in Iran. Using panel data covering the 2006-2015 period for 31 provinces of Iran and applying a dynamic system and the difference Generalized Methods of Moments (GMM) methods, we find that an increase in the balance of water (reducing the severity of drought) within provinces has a positive effect on property prices. Our results are robust, controlling for province fixed effects, time trend, and a set of control variables that may affect property prices.
\end{abstract}

Keywords Drought $\cdot$ Property prices $\cdot$ Residential land $\cdot$ Housing $\cdot$ Iran

JEL Classification R21 R R1 $\cdot$ Q54

Mohammad Reza Farzanegan

farzanegan@uni-marburg.de

Mehdi Feizi

feizi@um.ac.ir

Hassan F. Gholipour

H.Fereidouni@westernsydney.edu.au

1 Economics of the Middle East Research Group, Center for Near and Middle Eastern Studies (CNMS) \& School of Business and Economics, Philipps-Universität Marburg, Marburg, Germany

2 Faculty of Economics and Administrative Sciences, Department of Economics, Ferdowsi University of Mashhad, Mashhad, Iran

3 School of Business, Western Sydney University, Sydney, Australia 


\section{Introduction}

The purpose of this study is to examine the impact of drought on property prices in provinces of Iran throughout 2006-2015. A few works to date on global warming/climatic factors and property prices have attempted to examine the impact of changes in the severity of drought on housing and residential land prices in the Middle East and North Africa (MENA) region. Our study addresses this gap in the literature.

In this study, we extend the growing literature on the socio-economic consequences of climate change by examining the effect of meteorological factors on housing and residential land prices in Iran. We hypothesize that increases in property prices are stronger in those provinces with less water scarcity. Our hypothesis is motivated by findings of studies, which argue that higher housing values are associated with better amenities such as environmental improvement (Polinsky and Rubinfeld 1977; Roback 1982; Ho and Hite 2008; Huang et al. 2015; Galinato and Tantihkarnchana 2018).

The case of Iran, which has special climate features, would give us a unique design setting to conduct this study and provide new insights from the Middle East. Iran is a country with significant cross-sectional variations in amenities and climate. While the country has been hit hard by drought, provinces of Iran are not equally affected by water shortage. Moreover, unlike countries such as Malaysia or Finland, the provinces in Iran have different climates types. ${ }^{1}$ Thus, it is interesting to investigate how the regional property markets behave given such meteorological diversity. For example, our sample includes Mazandaran province with Caspian mild climate and East Azerbaijan province which has a cold mountain climate. Therefore, Iran's geographic vastness offers significant spatial variation in climate-related variables and people in its different regions have been suffering from consequences of climate change, particularly water shortage. ${ }^{2}$

We focus on the property (especially residential land asset) because it accounts for about $40 \%$ of national net capital stock in 2015, according to the Central Bank of Iran. ${ }^{3}$ The volume of residential land transactions was 137,477 units in 2006 , with the volume climbing to 298,463 units in 2011, according to a series of surveys conducted by the Statistical Centre of Iran. ${ }^{4}$ Therefore, any significant depreciation or appreciation of property prices would have substantial impacts on the wealth of households and investors.

Changes in housing prices matter for non-performing mortgages (Tajaddini and Gholipour 2017) which can have significant effects on bank balance sheets and the ability of banks to extend credit to households and businesses (Muellbauer 2012). Additionally, investors can change the residential land use (after the acquisition of land) for different purposes depending on business opportunities in various economic sectors (Gholipour and Lean 2017). Moreover, land use regulations are not well developed and well implemented and there is a substantial level of corruption among public officials who should be implementing the existing land use regulations (Sodaei 2015). It has also been shown that changes in property prices influence

\footnotetext{
${ }^{1}$ Different climates of Iran include Caspian mild and wet, Caspian mild, Mediterranean with Spring rains, Mediterranean, cold mountains, very cold mountains, cold semi-desert, hot semi-desert, dry desert, hot dry desert, hot coastal dry and coastal dry.

${ }^{2}$ For a critical review of water stress in Iran, see a comprehensive report by the Islamic Parliament Research Center of Iran (2017).

${ }^{3}$ See https://tsd.cbi.ir/DisplayEn/Content.aspx (in Farsi, accessed 24.06.2020)

${ }^{4}$ See http://www.amar.org.ir/Portals/0/Files/abstract/1391/ch_bongah_91.pdf (in Farsi, accessed 24.06.2020)
} 
divorce rate, family formation, and income inequality in Iran (Farzanegan and Gholipour 2016; Farzanegan et al. 2016a, b; Gholipour and Farzanegan 2015).

This paper makes two contributions to the literature. First, the effect of climatological factors, climate change and environmental disasters on property prices are not well explored in the literature out of the U.S. (e.g. Butsic et al. 2011; Galinato and Tantihkarnchana 2018; Glaeser et al. 2008; Mendelsohn et al. 1994; Schlenker et al. 2005; Bunten and Kahn 2014; Eichholtz et al. 2018; Petkov 2018), Australia (Rajapaksa et al. 2017), Germany (Hamilton 2007), China (Huang et al. 2015) and Japan (Zhai et al. 2003). In particular, this issue for Middle Eastern countries is under-investigated.

Second, previous studies examining the link between climatic factors and property prices have mainly focused on housing prices (Harrison et al. 2001; Bernstein et al. 2019) and farmland prices (Mendelsohn et al. 1994). Our research is the first to examine the effects of climatological factors on not only housing prices, but also residential land prices in Iran. To the best of our knowledge, there is no empirical work on the effect of drought on property prices for Iran.

Using dynamic system as well as difference Generalized Methods of Moments (GMM) estimators, our results show that intensifying drought reduces significantly the property values across Iran, controlling for other drivers of property prices.

To set the scene, the next section reviews the literature on drought in Iran and climate change-property prices nexus. The section after describes the data and our empirical strategy. The results and robustness checks are presented and discussed in the fourth section. Concluding remarks are presented in the fifth section.

\section{Review of Literature}

\section{Drought in Iran}

Iran has been experiencing long cycles of drought for the last 50 years. According to the Iranian Energy Minister " 334 cities with 35 million people across Iran are currently struggling with water stress" (Radio Farda 2018). The UN Development Program Resident Representative in Iran Gary Lewis also acknowledges the crisis: "The water shortage is currently Iran's most important humanitarian challenge," (Radio Farda 2018). In recent years, the water shortage and drought ${ }^{6}$ in Iran have caused substantial economic costs, several social issues, health problems, and violent conflicts.

In terms of water scarcity, Iran and other MENA countries have the highest expected economic losses from climate-related water scarcity, estimated at 6-14\% of Gross Domestic Product (GDP) by 2050 (World Bank 2016). Salami et al. (2009) also estimate the direct costs of drought on the total value added of the agricultural sector of the Iranian economy and its indirect impacts on the rest of the economy. Their results show that a drought, such as the one that occurred in the crop year 1999-2000, decreases overall GDP by about 4.4\%, leading to lower non-oil exports, rising food imports, and inflation.

\footnotetext{
${ }^{5}$ According to the European Environment Agency, water stress happens when the "demand for water exceeds the available amount during a certain period or when poor quality restricts its use".

${ }^{6}$ For a review of definitions of drought and its conditions, see Hendy et al. (2018).
} 
Drought has also driven many people from their homes in Iran. According to Hadi Ghaemi, the executive director for the Center for Human Rights in Iran (CHRI) "Towns and villages around Isfahan have been hit so hard by drought and water diversion that they have emptied out and people who lived there have moved" (Dehghanpisheh 2018).

Iran's environmental challenges have attracted considerable attention from Iranian researchers in recent years. For example, using data for 16,586 firms from more than 80 counties of Iran over the 2003-2011, Birjandi and Yousefi (2018) find that dust emissions reduce manufacturing firm productivity. They argue that dusty days disrupt access to raw materials and increase the cost of transportation for manufacturing firms. In particular, they show that lowering the number of days with dust storms by 1 day nationwide would increase the average firm's gross output by $0.081 \%$ and increase gross output across all firms by $\$ 149$ million. ${ }^{7}$

\section{Relationship between Climate Change and Property Prices}

In this section, we summarize some related studies and explain how climatic factors may influence property prices. The majority of related studies have focused on the effect of global warming and its consequences on property prices. These studies generally conclude that warming substantially undermines property prices.

For example, Butsic et al. (2011) find that global warming and reduction in snowfall intensity reduce residential property prices around major ski resorts in the western United States and western Canada. Using data from the U.S. counties, Mendelsohn et al. (1994) show that a change in temperature and/or precipitation (which was interpreted as the impact of climate change) is associated with a change in farmland value. More specifically, they find that a higher temperature in all seasons except Autumn reduces average agricultural land values, while more precipitation outside of Autumn increases land values.

Schlenker et al. (2005) also find a significant impact of climate change on farmland values in the U.S. Glaeser et al. (2008) note that climate-related amenity variables (temperature and precipitation) are important demand-side determinants of housing prices. Using a hedonic property value analysis, Yusuf and Resosudarmo (2009) find that air pollutants have an adverse relationship with property value, i.e., housing rental price, in Jakarta.

Other things being equal, people prefer housing in locations that offer a higher quality of life. Anwar et al. (2020) used water security as a proxy for security in a broader view and worked on the nexus between water, security, and gender in Karachi's informal settlements. They show that the struggle of living in an environment with water scarcity blocks peoples' abilities not only to live a secure life especially for women but also to keep a sustainable livelihood.

Huang et al. (2015) argue that better amenities affect the housing prices directly (as people are willing to pay for them), and indirectly, as an improvement of local amenities may enable the same group of employees to generate more output, as well as attract more capable people to

\footnotetext{
${ }^{7}$ Using data from 36,787 patients at the emergency centres of Tehran in 2013, Motasedi et al. (2016) show that there is a significant association between the risk of respiratory diseases and carbon monoxide and sulfur dioxide pollutants. Using Iran's national census data from 1996 to 2011, Shiva and Molana (2019) find that interprovince migration is significantly and consistently affected by province-level average levels of annual temperature and precipitation. Feizi et al. (2019) also provide evidence that rainfall shortage led to more violent and antisocial behavior across provinces of Iran from 2007 to 2014. The competition to get access to water resources, which have no substitute, could lead people to exhibit selfish and even hostile behaviors. Moreover, the shortage of precipitation might reduce the income of people, for example in the agricultural sector, and hence the associated tension and stress could drive people to violence.
} 
that region and raise the aggregate income of the region. As housing is a durable and immobile consumption good, location and local amenities matter. Huang et al. (2015) find that their measure of climate factors (which includes extreme temperatures, temperature difference, amount of annual sunshine, precipitation, and relative humidity) has a significant and positive impact on housing prices in China.

The other strand of literature in this area is related to the effect of flood and sea level rise (due to global warming) on property prices (e.g. Rajapaksa et al. 2017; Eves and Wilkinson 2014; Bin and Landry 2013; Samarasinghe and Sharp 2010; Lamond et al. 2010; Speyrer and Ragas 1991; Zhai et al. 2003; Harrison et al. 2001; Tobin and Newton 1986; Ortega and Tașpınar 2018; Bernstein et al. 2019). Commonly, these studies find a negative impact of flooding and sea level rise on housing and land prices. For example, using U.S. data, Bernstein et al. (2019) show that coastal properties exposed to sea level rise sell at about $7 \%$ less than observably equivalent unexposed properties equidistant from the beach.

Since many researchers are in favor of the negative impact of severe climate factors on property prices, we hypothesize that those provinces of Iran with less water scarcity experience stronger growth in property prices.

\section{Data and Model Specification}

Our empirical analysis is based on annual data for 31 provinces of Iran from 2006 to 2015. We use annual changes in average housing prices per square meter (1000 IRR) and average land price per square meter of old houses 8 (1000 IRR). Data for housing prices and land prices are obtained from the Statistical Center of Iran.

To measure the variability of drought conditions in Iran, we use annual changes in the Standardized Precipitation-Evapotranspiration Index (SPEI). This index is based on the difference between precipitation and potential evapotranspiration. It is an improved drought index to study the consequences of global warming on drought severity (Beguería et al. 2014). The SPEI considers the effect of reference evapotranspiration on drought severity. In addition, the multi-scalar nature of the SPEI enables identifying, monitoring, and analyzing the initiation, length, and intensity of drought conditions and identification of different drought types and drought impacts on diverse systems. It values between -5 and 5 , where smaller values indicate stronger degrees of drought and larger values indicate higher degrees of moisture. SPEI is a standardized z-score that is calculated by subtracting the 30 years mean from drought primary data and then dividing by its standard deviation. It determines the number of standard deviations that the value of primary data on drought is higher or less than its mean over 30 years. Non-standardized drought data higher than the mean have positive z-score, while those less than the mean have negative z-scores.

The SPEI is used frequently in the related literature to study climate change (e.g. Abiodun et al. 2013; Yu et al. 2014) and the effects of drought on agriculture (Potop et al. 2012) as well as ecological systems (e.g. Vicente-Serrano et al. 2012; Barbeta et al. 2013; Cavin et al. 2013). This index is also used in drought monitoring systems (Svoboda et al. 2015). In our sample of Iranian provinces from 2006 to 2015 , the SPEI varies from -2.5 to 1.4. The negative values show decreasing/drying trends in the SPEI while the positive figures indicate an increasing/

\footnotetext{
${ }^{8}$ As defined by the Statistical Center of Iran, old houses are those residential buildings that have been traded in order to completely destroy the building and construct a new building on its land.
} 
wetting trend (Somorowska 2016). Data on SPEI is collected from the Iran National Drought Warning and Monitoring Center. ${ }^{9}$

We expect that improving SPEI (better water balance) positively affects the environmental condition and its attractiveness for residents. In turn, this will have a positive effect on the real estate value, ceteris paribus. In contrast, shrinking values of SPEI indicate the worsening of the local climate and harsher climatic living situations; thus, by reducing accommodation, demand will negatively affect the value of properties. ${ }^{10}$ Figs. 1 and 2 show the scatterplot of logarithm of housing prices and land prices with SPEI for each province over time.

In addition to our main variable of interest (water balance), we also control for annual changes in major macroeconomic and amenity determinants of property prices involving economic activities, interest rate, construction costs, and leisure, cultural and sport (LCS) and the share of agricultural value added in GDP. It is expected that an increase in economic activities through, e.g. an increase in employment (and resulting hikes in households' labor income) or real industrial production increases households' income and hence the demand for properties. Since the real estate stock (supply) cannot change in the short run, a shock in demand for real estate, reflected in rents increases, would lead to higher property prices (Adams and Füss 2010). Real gross domestic product per capita (GDP $p c$ ) is used as a proxy for economic activities. The GDP per capita series are obtained from the Statistical Center of Iran.

In this study, we use the real interest rate for construction and housing loans ${ }^{11}$ by subtracting the nominal interest rate ${ }^{12}$ from the inflation rate of each province. We expect a negative relationship between long-term interest rates and real estate prices. A higher longterm interest rate can reduce real estate prices in two ways (Adams and Füss 2010). First, a higher long-term interest rate increases the return of other fixed-income assets (such as bonds) relative to the return of real estate, thus, shifting the demand from real estate into other assets, leading to lower real estate prices. Second, a higher long-term interest rate is reflected in higher mortgage rates, which reduces demand and decreases real estate prices.

Data on housing construction costs (IRR), e.g. construction materials or labor costs, per square meter are sourced from the Building Statistics section of Economic Statistics of the Central Bank of Iran. The higher construction costs lead to a decrease in construction and housing supply which in turn raises the property value. Thus, we expect that higher construction costs are positively associated with higher housing and residential land prices.

We also control for an amenity variable in our estimations involving local leisure, cultural, and sport infrastructure and facilities. It is expected that greater availability of these facilities and services positively affect the local living condition, increase the demand for properties, and as a result boost the value of properties. As a proxy for these facilities and services, we use the share of gross value added $(G V A)$ of leisure, cultural, and sport $(L C S)$ in each province. The data are obtained from regional accounts of the Statistical Center of Iran.

\footnotetext{
${ }^{9}$ See http://ndc.irimo.ir/far/wd/4625-SPEI.html (in Farsi, access 24.06.2020)

${ }^{10}$ For a review of calculations of the SPEI, the theory behind it and its comparison to other available drought indexes, see Vicente-Serrano et al. (2010a, 2010b) and Beguería et al. (2014).

${ }^{11}$ In Economic Times Series Database, this is called "Expected Rate of Return on Facilities," https://sd.cbi.ir/ DisplayEn/Content.aspx (in Farsi)

12 The nominal fixed interest rates, on both deposits and lending, are determined by the Central Bank of Iran in the second month of each year in the Iranian Calendar (about April), and financial institutions are obliged to follow this rate in their operations" (https://www.imf.org/ /media/Files/Publications/CR/2017/cr1763.ashx, accessed 24.06.2020)
} 


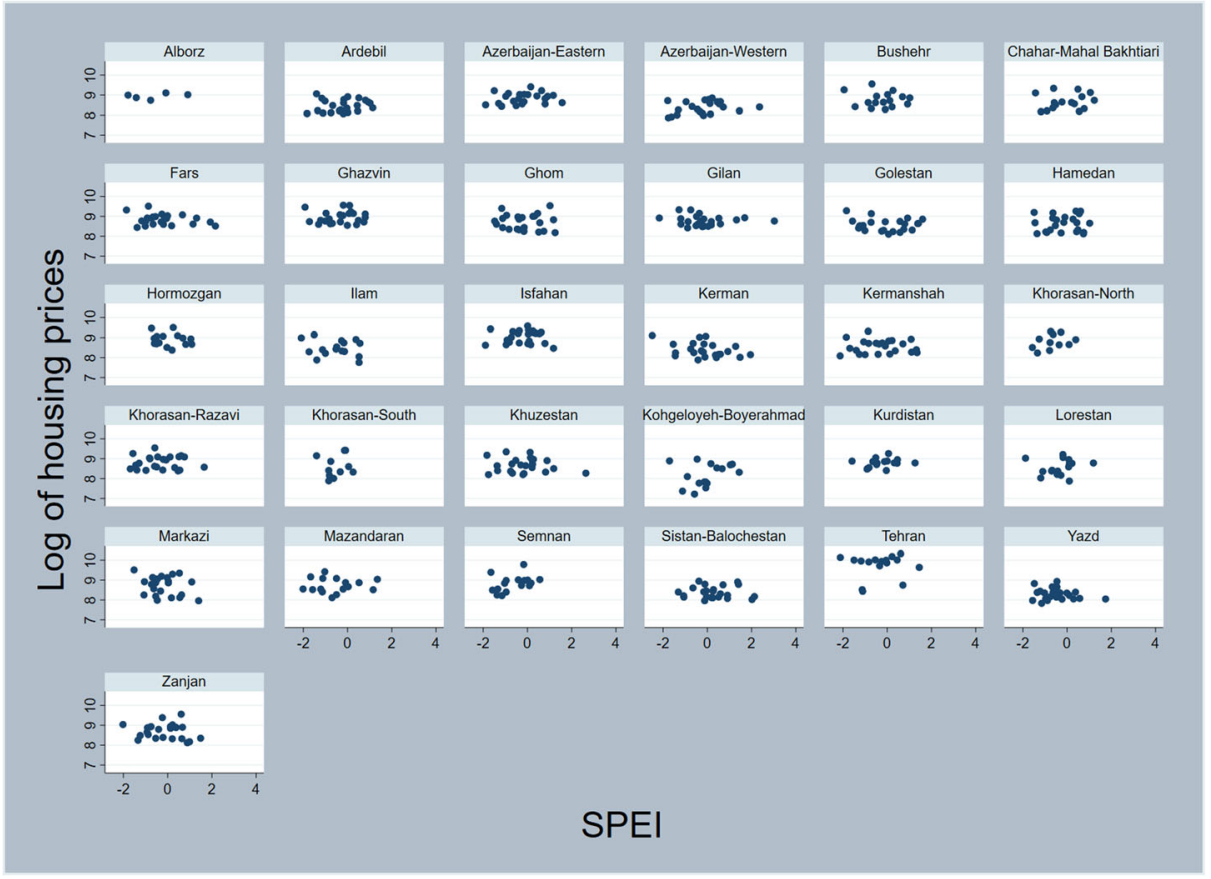

Fig. 1 Association between logarithm of housing prices and SPEI within Iranian provinces. (Source: Authors' Calculation)

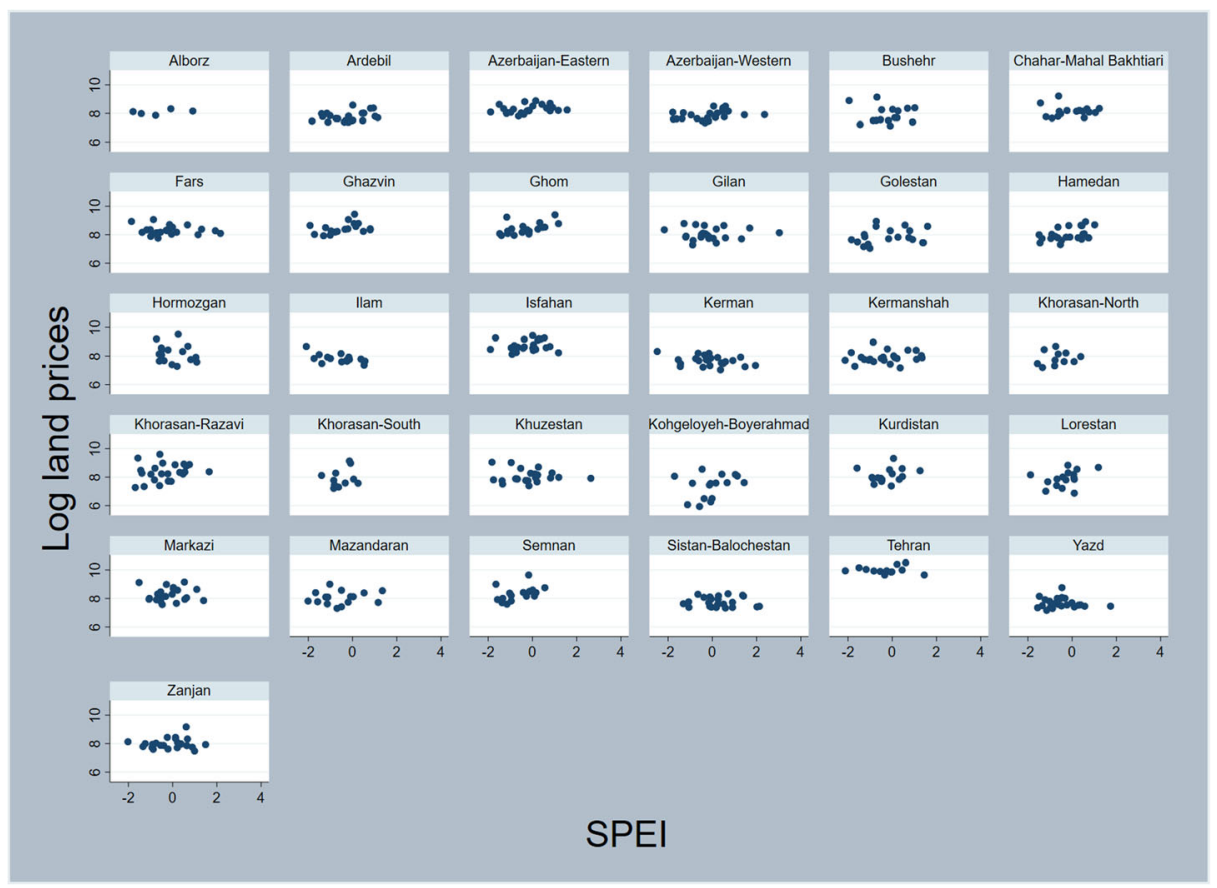

Fig. 2 Association between logarithm of land prices and SPEI within Iranian provinces. (Source: Authors' Calculation) 
Drought may affect property prices not only through amenity values but also through decreases in revenues from agricultural outputs. In the regressions, we do account for changing shares of agricultural outputs, which would be affected by drought and are relevant for property prices. Controlling for the share of regional agricultural value added in GDP of provinces helps us to show if the drought effect comes through amenity values or agricultural production.

We also use a dummy variable related to Maskan-e Mehr building (“Affordable Housing") national project (2009-2015). The Maskan-e Mehr has entailed granting "preferential housing finance and construction tax exemptions to homes constructed on designated public lands for low-income households" (Alaedini and Ashrafzadeh 2016, 17-18). At least, the Iranian experience shows that governments, in parallel with private sector participation, can play a significant role in the provision of housing for low- and middle-income groups through direct provision of urban lands (Keivani et al. 2008). By allocating free-of-charge land to low-income groups, the Iranian government aimed for lowering the construction costs and making the accommodation more affordable for the poor. We should also note that while the Maskan-eMehr project was implemented during the period of 2009-2015, some severe economic and energy sanctions were also imposed on Iran from 2012 to 2015 (Farzanegan 2013 provides an overview of economic distortions that these sanctions introduced). Economic sanctions from 2012 to 2015 had a significant negative impact on both the formal and informal economies of Iran (Farzanegan and Hayo 2019). ${ }^{13}$ In short, we expect to observe a negative effect of Dummy 2009-2015 (which captures the government housing policy of Maskan-e-Mehr and sanctions on housing prices). Table 3 in the Appendix presents the data and sources. Table 4 shows the summary statistics of variables in the panel analysis. ${ }^{14}$

We use first difference of variables in our estimation. This helps to render our data stationarity. The non-stationarity of variables may lead to spurious relationships in panel regression as in time series estimations. Panel unit-root tests in short panels (as in our case) are unreliable (Farzanegan and Hayo 2019). Taking the first difference of variables help to remove stochastic and deterministic trends from our data at a province level. In addition, to capture possible trends, we include the time trend and two lags of the dependent variable in our set of control variables.

Given the above discussion and following DiPasquale and Wheaton (1992) and Oikarinen et al. (2018), our empirical analysis lies in a conventional housing market stock-flow model that includes three key determinants of the long-term equilibrium for housing prices (logarithm $(\log )$ of $H P$ ) or land prices $(\log$ of $L P)$ : real income $(\log$ of $G D P c$.), real interest rate $(I R)$, and real construction costs per square meter $(\log$ of $C C)$. All variables are in their first differences (D).

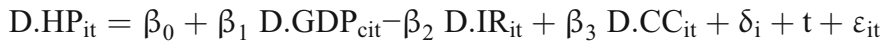

We extend Eq. (1) by including our variables of interest, namely climate change, an important amenity variable, $L C S$, and finally an exogenous dummy variable to cater for the structural changes, i.e., Maskan-e Mehr (2009-2015). It should be noted that we use province consumer

\footnotetext{
${ }^{13}$ A significant reduction of effective demand and welfare of Iranian households under sanctions by using computable general equilibrium model based on a social accounting matrix is also shown by Farzanegan et al. (2016a, 2016b).

${ }^{14}$ We do not include the spatial component in our empirical model (to capture spatial spillover effects) because some studies in Iran show that house prices in provinces of Iran are not strongly connected (Gholipour and Lean 2017).
} 
price index $(C P I)$ to calculate the real values of nominal variables. We also control for the past development of housing and land prices by including their lags as explanatory variables.

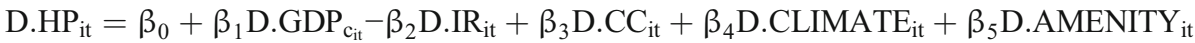

$$
\begin{aligned}
& +\beta_{6} \text { D.AGRICULTURE }_{\mathrm{it}}+\beta_{7} \text { MASKAN }-e-M E H R \text { dummy }+\beta_{8} \cdot \text { D.HP }_{\mathrm{it}}-1 \\
& +\beta_{9} \cdot \mathrm{D} \cdot \mathrm{HP}_{\mathrm{it}-2}+\delta_{\mathrm{i}}+\mathrm{t}+\varepsilon_{\mathrm{it}}
\end{aligned}
$$

We estimate a similar regression for land prices as well. Based on the earlier theoretical discussions, we expect to observe a positive effect of an increase in the balance of water (reducing the severity of drought) on the increase of real estate prices $\left(\beta_{4}>0\right)$, ceteris paribus.

Inclusion of lags of dependent variables in our fixed effects estimations may lead to the Nickell bias (Nickell 1981). While the effects of other variables including the drought index are estimated consistently, it could be possible that the lagged dependent variables are inconsistently estimated. To address the possibility of the Nickell bias, we use a different methodology than fixed effects, i.e., dynamic system GMM developed by Arellano and Bover (1995) and Blundell and Bond (1998). The GMM method differences the equation to get rid of any time-invariant country specific factors. This approach can also address any endogeneity that may be due to the correlation of these time invariant country characteristics and the explanatory variables (Baltagi et al. 2009).

We report both one and two-steps difference and system GMM estimation results. Baltagi (2008) shows that the system GMM produces more efficient and precise estimates compared to differenced GMM by enhancing precision and decreasing the finite sample bias. We use robust standard errors which are consistent with panel-specific autocorrelation and heteroskedasticity. We treat the lags of the dependent variable as well as other explanatory variables except for drought index (SPEI) and dummy variable as potentially endogenous variables and use 2 to 4 year lags as internal instruments.

\section{Empirical Results}

\section{Main Analysis}

The effect of intensity of drought on housing and land prices are shown in Tables 1 and 2. The dependent variables in both of these tables are the first difference of logarithm of housing or land prices, respectively. Our main variable of interest is the first difference of SPEI index. Both difference and system GMM estimation results support our earlier theoretical expectation in which an improvement in water balance (an increase in SPEI) is associated with a boost in housing and land values within provinces, controlling for other factors.

These findings provide support to our hypothesis that reduction of drought severity leads to higher property prices in Iran. In addition, our results are in line with findings of other research showing that climatic factors and climate change can have an important impact on property prices (e.g. Huang et al. 2015; Butsic et al. 2011; Harrison et al. 2001).

In Table 1, across different models, an increase by one unit in SPEI index (with a minimum of -2.5 and a maximum of 1.41) is associated with an approximate $8 \%$ increase in housing prices, controlling for other factors. In Table 2, on average and across different models, a one- 
Table 1 Dynamic panel regressions: difference and system GMM estimations (housing prices- SPEI nexus)

\begin{tabular}{|c|c|c|c|c|}
\hline & (1) & & & (4) \\
\hline & \multicolumn{4}{|c|}{ Dependent variable: D.log housing price } \\
\hline & $\begin{array}{l}\text { diff GMM } \\
\text { (2-steps) }\end{array}$ & $\begin{array}{l}\text { diff GMM } \\
\text { (1-step) }\end{array}$ & $\begin{array}{l}\text { SYS GMM } \\
\text { (2-steps) }\end{array}$ & $\begin{array}{l}\text { SYS GMM } \\
\text { (1-step) }\end{array}$ \\
\hline D.SPEI & $\begin{array}{l}0.086 * * * \\
(2.79)\end{array}$ & $\begin{array}{l}0.084 * * * \\
(3.97)\end{array}$ & $\begin{array}{l}0.082^{* * * *} \\
(3.25)\end{array}$ & $\begin{array}{l}0.077 * * * \\
(4.57)\end{array}$ \\
\hline D. $\log$ GDP per capita & $\begin{array}{l}0.199 \\
(0.89)\end{array}$ & $\begin{array}{l}0.245 \\
(1.46)\end{array}$ & $\begin{array}{l}0.081 \\
(0.30)\end{array}$ & $\begin{array}{l}0.177 \\
(1.05)\end{array}$ \\
\hline D. Interest rate & $\begin{array}{l}-0.462^{* * *} \\
(-2.13)\end{array}$ & $\begin{array}{l}-0.431 * * \\
(-2.13)\end{array}$ & $\begin{array}{l}-0.405^{*} \\
(-1.93)\end{array}$ & $\begin{array}{l}-0.376^{*} \\
(-2.02)\end{array}$ \\
\hline D. $\log$ Construction costs & $\begin{array}{l}0.527 \\
(1.00)\end{array}$ & $\begin{array}{l}0.779 * * \\
(2.26)\end{array}$ & $\begin{array}{l}0.981 * * \\
(2.06)\end{array}$ & $\begin{array}{l}0.956 * * \\
(2.62)\end{array}$ \\
\hline D. Share of value added of leisure, cultural and sport & $\begin{array}{l}0.160 \\
(0.70)\end{array}$ & $\begin{array}{l}0.064 \\
(0.30)\end{array}$ & $\begin{array}{l}0.030 \\
(0.13)\end{array}$ & $\begin{array}{l}-0.033 \\
(-0.18)\end{array}$ \\
\hline D. Share of value added of agriculture & $\begin{array}{l}0.033 * * * \\
(3.06)\end{array}$ & $\begin{array}{l}0.031 * * * \\
(3.66)\end{array}$ & $\begin{array}{l}0.027 * \\
(1.95)\end{array}$ & $\begin{array}{l}0.029 * * \\
(2.38)\end{array}$ \\
\hline Maskan -e- Mehr dummy & $\begin{array}{l}-0.784 * * * \\
(-3.73)\end{array}$ & $\begin{array}{l}-0.648 * * * \\
(-4.06)\end{array}$ & $\begin{array}{l}-0.583^{* *} \\
(-2.45)\end{array}$ & $\begin{array}{l}-0.549 * * * \\
(-2.79)\end{array}$ \\
\hline Time trend & $\begin{array}{l}0.050^{*} \\
(1.84)\end{array}$ & $\begin{array}{l}0.040^{*} \\
(1.88)\end{array}$ & $\begin{array}{l}0.026 \\
(1.05)\end{array}$ & $\begin{array}{l}0.026 \\
(1.44)\end{array}$ \\
\hline Lag1. D.log housing price & $\begin{array}{l}-0.989 * * * \\
(-5.17)\end{array}$ & $\begin{array}{l}-0.908 * * * \\
(-6.17)\end{array}$ & $\begin{array}{l}-0.890 * * * \\
(-3.39)\end{array}$ & $\begin{array}{l}-0.827 * * * \\
(-4.04)\end{array}$ \\
\hline Lag2. D.log housing price & $\begin{array}{l}-0.306 * * \\
(-2.68)\end{array}$ & $\begin{array}{l}-0.279 * * * \\
(-3.41)\end{array}$ & $\begin{array}{l}-0.303 * * * \\
(-3.47)\end{array}$ & $\begin{array}{l}-0.274 * * * \\
(-3.20)\end{array}$ \\
\hline Observations & 239 & 239 & 270 & 270 \\
\hline Hansen test of overid. Restrictions ( $p$ value) & 0.127 & 0.127 & 0.372 & 0.372 \\
\hline AR (1) ( $p$ value $)$ & 0.018 & 0.008 & 0.060 & 0.001 \\
\hline AR (2) (p value) & 0.104 & 0.060 & 0.306 & 0.134 \\
\hline
\end{tabular}

Note: Robust $\mathrm{t}$ statistics in parentheses. * $p<0.10$; ** $p<0.05$; *** $p<0.01$. Results generated using the xtabond2 command in Stata, with small sample adjustment for s.e., and assuming exogeneity of time trend, Maskan-e-Mehr dummy variable and SPEI. Endogenous variables are lags of the dependent variable, and other explanatory variables which are instrumented by 2-4 lags

unit increase in SPEI index is associated with an increase of approximately $12 \%$ in land prices, ceteris paribus. The SPEI has a stronger effect on the land price as a better climate makes land more valuable, not only for living but also for cultivation.

Regarding the control variables, we observe that after controlling for other intermediary channels that may affect real estate prices, the overall increase in GDP per capita with an expected positive sign, lacks statistical significance in predicting the boost of housing and land prices. In other words, more household income, and in turn higher demand for houses as well as land does not translate necessarily into higher prices since the growth of the supply side might backfire it.

The effect of rise in the real interest rate on the escalation of housing prices is negative and significant (Table 1). Higher levels of interest rates lower the effective demand of buyers in the real estate market and thus have a dampening effect on prices. Higher interest rates may also channelize the liquidity from the real estate market to the banking system, leading to lower prices in the former market.

Interestingly, interest rates do not have any significant impact on land prices. While Iran's banking system provides loans to purchase a house, there is no similar schema to support a household for buying land. Therefore, higher interest rates make house loans less attractive for 
Table 2 Dynamic panel regressions: difference and system GMM estimations (Residential land prices- SPEI nexus)

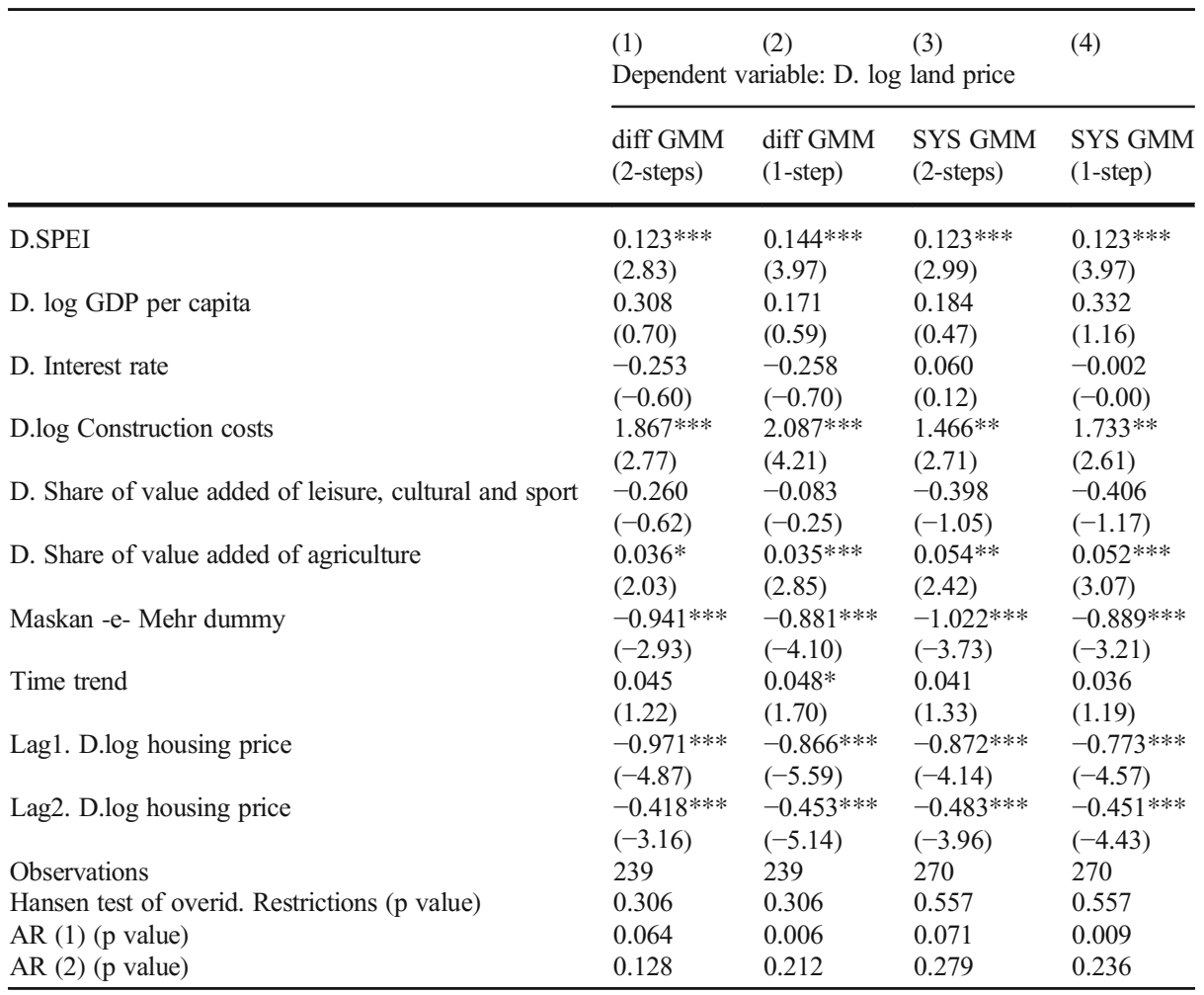

Note: Robust $\mathrm{t}$ statistics in parentheses. * $\mathrm{p}<0.10$; ** $\mathrm{p}<0.05$; *** $\mathrm{p}<0.01$. Results generated using the xtabond2 command in Stata, with small sample adjustment for s.e., and assuming exogeneity of time trend, Maskan-e-Mehr dummy variable and SPEI. Endogenous variables are lags of the dependent variable, and other explanatory variables which are instrumented by $2-4$ lags

households, reduce their willingness to buy, which in turn pushes down the house price, while higher interest rates do not affect land prices.

The increasing level of construction cost has a robust positive and statistically significant effect on housing and land prices. On average, a one-percent increase in construction costs has a positive impact on housing prices by approximately $1 \%$ (columns 3 and 4 of Table 1). Based on Table 2, a similar increase in construction costs has a stronger effect of approximately $2 \%$ on land prices. It has its highest effect on the land price as constructions and land are complementary goods and once the cost of the former increases, the latter also becomes more valuable. We identified no statistically significant association between shares of value added of leisure, cultural and sport in total value added of province and housing or land prices.

Furthermore, there is a positive and significant association between the share of value added of agriculture in regional GDP and housing and land prices. A higher level of agricultural outputs leads to a higher level of property prices because it generates income for local households which in turn boosts the demand for houses. In addition, more agricultural outputs in a province may attract more agricultural workers and leasers of agricultural land. Greater numbers of population may push property prices up. Moreover, as agricultural land and 
residential land are weak substitutes, the higher demand for the former, due to more expected product, leads to higher demand for the latter and in turn higher prices. In other words, once agricultural land generates more products, it makes less sense to use them as a residential land.

The dummy variable for national Maskan-e Mehr housing project in addition to the negative effects of sanctions on household effective demand also shows a significant negative association with housing and residential land prices. For example, based on Model 1 in Table 1, during 2009-2015 and under the implementation of Maskan-e-Mehr (and sanctions), housing prices growth rates were, on average, 0.78 percentage points lower than other years.

This dummy variable has the highest effect on the land price (a reduction of 0.94 percentage points in Model 1 in Table 2) since Maskan-Mehr plan aimed to supply free lands for housing projects of lower-income classes. Therefore, this project boosted the land supply in the short run and had a remarkable dampening effect on the land price. As a result, this countrywide project also reduces housing prices.

The model does not suffer from autocorrelation and the autocorrelation tests of first and second degrees are satisfactory: as expected, there is high first-order autocorrelation and no evidence for significant second-order autocorrelation. If the instruments are appropriately uncorrelated with the errors, then we expect to reject the presence of the second order serial correlation (Bjorvatn and Farzanegan 2013). In addition, the null hypothesis of the validity of the over-identifying restrictions based on the Hansen test cannot be rejected, indicating a wellspecified model across different specifications. For sensitivity checks, we replaced SPEI index with the log of average annual temperature and the log of annual rainfalls. As we expected, we observed a negative effect of higher temperatures and a positive effect of higher rainfalls within provinces on the housing and land values. ${ }^{15}$ In addition, we checked for multicollinearity by examining the variance inflation factors (VIFs) for the independent variables specified in our linear regression model. We observed that none of VIFs is larger than 10 .

We perform a number of robustness checks to confirm the validity of our main results, which are explained in the following sections.

\section{Robustness Check with Stepwise Regression}

We also estimate our model using a different specification in which control variables are added one after the other. Thus, the first model includes our main variable of interest (SPEI) and in other specifications, we control for other explanatory variables. We do the approach for difference GMM and System GMM (two steps) for housing prices as a dependent variable. As can be seen from Tables 5 and 6 in Appendix, the effect of SPEI is robust in its sign and significance. The first model which only includes SPEI (along with Maskan-e-Mehr dummy, time trend, and lags of the dependent variable) does not pass AR(2) criteria in GMM estimation while other models perform well on this test and Hansen statistics. The estimation

\footnotetext{
${ }^{15}$ The results are available upon request. We also used SPI index and the results do not change. The estimation results using the SPI index are available upon request. Data on SPI are collected from the Iran National Drought Warning and Monitoring Center. SPI and SPEI are closely related to each other. In the SPI, we only take into account the amount of precipitation as the main input for calculations. However, the SPEI is an index for "climatic water balance". It is a difference between precipitation and reference evapotranspiration, i.e., P - PET. In other words, it is a comparison between available water $(\mathrm{P})$ and potential evapotranspiration (PET). Therefore, it is a more reliable measure of drought severity compared to SPI which relies only on precipitation.
} 
results of difference and system GMM, especially with reference to SPEI are close to each other.

\section{Robustness Check with an Alternative Estimator}

In addition to GMM estimations, we also apply a long difference (LD) estimator to examine the relationship between SPEI and property prices. ${ }^{16}$ We have followed a procedure as described in Hahn et al. (2007) which is suitable in dynamic panel regressions with persistent data series and a short time dimension as well as fixed effects. Hahn et al. (2007) also show that LD estimation is less biased compared to standard GMM estimators like Blundell/Bond. The LD estimator uses the Two-Stage least squares (2SLS) estimation applying lagged levels of the regressors and the residuals as instruments. The LD estimator builds on the model of Hahn et al. (2007) and allows for unbalanced panel data with a lagged dependent variable. We use "XTLD" program developed by Catharina Klepsch to implement the long-difference estimator by Hahn et al. (2007) in Stata. The default value for the number of iterations is 3, following Hahn et al. (2007) and the default for the lag length (the number of differencing lengths) is 5 (years).

The obtained results following LD estimations for housing prices as a dependent variable is shown in Table 7 in Appendix. As can be seen, the drought index in LD estimation has a similar sign and significance as in GMM models, although the impact size is slightly less. A one-unit increase in the SPEI over the last 5 years is associated with an approximate 4\% increase in housing prices. When we use the land price as the outcome variable, the effect of SPEI is still positive in sign but is not statistically significant anymore. In the estimations related to the land price using the long difference approach, the past 5 years development of land prices, the past 5 years development of value-added of agriculture in province, and time trend are statistically significant.

\section{Conclusion}

Our study of 31 Iranian provinces from 2006 to 2015 shows that climate condition matters in housing and residential land prices. Our panel dynamic GMM estimations provide strong evidence on the importance of drought severity as a factor, which substantially reduces the value of properties. This finding is robust while controlling for other determinants of property prices, e.g. regional economic development, real interest rates, construction costs, regional value added in sectors such as sports, cultural, and leisure, the share of agricultural value added in regional GDP, and earlier developments of housing and land prices. Furthermore, we control for the implementation of the national housing project aimed to supply affordable houses for low-income groups.

These results extend our understanding of the socio-economic consequences of climate change in Iran and provide important implications for Iranian policymakers and property investors. On the one hand, decreases in property prices in provinces, which have been experiencing drought, would significantly reduce aggregate consumption and investment

\footnotetext{
${ }^{16}$ We have also estimated the models using fixed effects regressions which exclude the lags of the dependent variable and use robust standard errors. Overall, the results (unreported) show that the effect of SPEI on housing prices is positive as was also shown in GMM estimations. The size of the effect, on average, is lower than the results in GMM (it is like the size in the first model of GMM which only includes SPEI and lags of dependent variables as well as policy dummy and trend). The results of fixed effects regressions are available upon request.
} 
through real estate wealth effect and collateral effect in those provinces. On the other hand, households in provinces with less of a water crisis would enjoy higher consumption through real estate wealth and collateral effects. Therefore, we should expect a long-run consumption and investment inequality across provinces of Iran, assuming that the governments do not intervene in the water crisis and drought and do not change the re-distribution policies.

Finally, our analyses suggest that property investors can gain from investing in provinces with more precipitation. Future research may extend our work and explore the impact of drought on property prices at the city-level if official data become available for several cities over time.

Acknowledgements The authors are grateful for useful comments from Editor (Ilan Noy), and two anonymous referees.

Funding Open Access funding enabled and organized by Projekt DEAL.

\section{Appendix}

Table 3 Data description

\begin{tabular}{|c|c|c|}
\hline & Definition & Data sources \\
\hline Housing prices & $\begin{array}{l}\text { Average housing prices per square } \\
\text { meter (1000 IRR) }\end{array}$ & Statistical Center of Iran \\
\hline Residential land prices & $\begin{array}{l}\text { Average land price per square meter } \\
\text { of old houses (1000 IRR) }\end{array}$ & Statistical Center of Iran \\
\hline SPEI & $\begin{array}{l}\text { Standardized } \\
\text { Precipitation-Evapotranspiration } \\
\text { Index }\end{array}$ & $\begin{array}{l}\text { Iran National Drought Warning } \\
\text { and Monitoring Center }\end{array}$ \\
\hline GDPpc & Gross domestic product per capita & Statistical Center of Iran \\
\hline Real interest rate & $\begin{array}{l}\text { Expected rates of return facilities } \\
\text { (construction and housing) }\end{array}$ & $\begin{array}{l}\text { Central Bank of Iran \& authors' } \\
\text { calculation }\end{array}$ \\
\hline Construction costs & $\begin{array}{l}\text { Residential construction costs per } \\
\text { square meter (rial) }\end{array}$ & $\begin{array}{l}\text { Central Bank of Iran, Economic } \\
\text { Statistics, Building Statistics } \\
\text { https://www.cbi.ir/simplelist/4300.aspx }\end{array}$ \\
\hline $\begin{array}{l}\text { Leisure, cultural and sport } \\
\text { value } \\
\text { added ( } \% \text { total value added) }\end{array}$ & $\begin{array}{l}\text { Share of leisure, cultural and sport } \\
\text { activities in total GDP }\end{array}$ & Statistical Center of Iran \\
\hline $\begin{array}{l}\text { Agricultural value added } \\
\text { (\% total value added })\end{array}$ & $\begin{array}{l}\text { Share of agricultural outputs in total } \\
\text { GDP }\end{array}$ & Statistical Center of Iran \\
\hline
\end{tabular}

Table 4 Summary statistics

\begin{tabular}{|c|c|c|c|c|c|}
\hline Variable & Obs. & Mean & Std. Dev. & Min & $\operatorname{Max}$ \\
\hline First difference of log of housing prices & 239 & -0.13 & 0.13 & -1.06 & 0.17 \\
\hline First difference of log of land prices & 239 & -0.19 & 0.24 & -1.29 & 0.57 \\
\hline First difference of log of GDP pc & 239 & -0.02 & 0.11 & -0.57 & 0.38 \\
\hline First difference of interest rate & 239 & 0.01 & 0.11 & -0.14 & 0.27 \\
\hline First difference of log of construction costs & 239 & -0.03 & 0.10 & -0.49 & 0.42 \\
\hline First difference of SPEI & 239 & -0.04 & 1.21 & -2.73 & 3.17 \\
\hline First difference of Share of value added of leisure, cultural and sport & 239 & -0.07 & 0.22 & -1.54 & 0.52 \\
\hline First difference of Share of value added of agriculture & 239 & 0.13 & 2.89 & -9.00 & 7.55 \\
\hline Maskan-e-Mehr dummy & 239 & 0.88 & 0.32 & 0.00 & 1.00 \\
\hline
\end{tabular}


Table 5 Stepwise regression using difference GMM-two steps
(1)
(2)
(3)
(4)
(5)
(6)

Dependent variable: D.log housing price

\begin{tabular}{|c|c|c|c|c|c|c|}
\hline Lag2. D.log housing price & $\begin{array}{l}-0.304 * * * \\
(-6.76)\end{array}$ & $\begin{array}{l}-0.364 * * * \\
(-4.42)\end{array}$ & $\begin{array}{l}-0.279 * * \\
(-2.52)\end{array}$ & $\begin{array}{l}-0.315 * * * \\
(-3.87)\end{array}$ & $\begin{array}{l}-0.327 * * \\
(-2.62)\end{array}$ & $\begin{array}{l}-0.306 * * \\
(-2.68)\end{array}$ \\
\hline D.SPEI & $\begin{array}{l}0.045^{* * * *} \\
(4.12)\end{array}$ & $\begin{array}{l}0.085 * * * \\
(3.07)\end{array}$ & $\begin{array}{l}0.087 * * * \\
(3.46)\end{array}$ & $\begin{array}{l}0.118 * * * \\
(4.20)\end{array}$ & $\begin{array}{l}0.092 * * * \\
(2.96)\end{array}$ & $\begin{array}{l}0.086^{* * * *} \\
(2.79)\end{array}$ \\
\hline D. Interest rate & & & $\begin{array}{l}-0.316 \\
(-1.43)\end{array}$ & $\begin{array}{l}-0.642 * * * \\
(-2.86)\end{array}$ & $\begin{array}{l}-0.489 * * \\
(-2.21)\end{array}$ & $\begin{array}{l}-0.462 * * \\
(-2.13)\end{array}$ \\
\hline $\begin{array}{l}\text { D. Share of value added of leisure, } \\
\text { cultural and sport }\end{array}$ & & & & $\begin{array}{l}0.550 * * \\
(2.55)\end{array}$ & $\begin{array}{l}0.258 \\
(1.16)\end{array}$ & $\begin{array}{l}0.160 \\
(0.70)\end{array}$ \\
\hline $\begin{array}{l}\text { D. Share of value added of } \\
\text { agriculture }\end{array}$ & & & & & $\begin{array}{l}0.027 * * \\
(2.07)\end{array}$ & $\begin{array}{l}0.033 * * * \\
(3.06)\end{array}$ \\
\hline Maskan -e- Mehr dummy & $\begin{array}{l}-0.338 * * * \\
(-6.85)\end{array}$ & $\begin{array}{l}-0.051 \\
(-0.46)\end{array}$ & $\begin{array}{l}-0.041 \\
(-0.39)\end{array}$ & $\begin{array}{l}-0.441 * * \\
(-2.20)\end{array}$ & $\begin{array}{l}-0.764 * * * \\
(-3.45)\end{array}$ & $\begin{array}{l}-0.784 * * * \\
(-3.73)\end{array}$ \\
\hline Time trend & $\begin{array}{l}0.009 * * \\
(2.33)\end{array}$ & $\begin{array}{l}-0.014 \\
(-1.62)\end{array}$ & $\begin{array}{l}-0.009 \\
(-1.08)\end{array}$ & $\begin{array}{l}0.044^{*} \\
(1.77)\end{array}$ & $\begin{array}{l}0.049^{*} \\
(1.81)\end{array}$ & $\begin{array}{l}0.050 * \\
(1.84)\end{array}$ \\
\hline Observations & 477 & 239 & 239 & 239 & 239 & 239 \\
\hline $\begin{array}{l}\text { Hansen test of overid. Restrictions } \\
\quad \text { (p value) }\end{array}$ & 0.044 & 0.089 & 0.186 & 0.184 & 0.146 & 0.127 \\
\hline AR (1) (p value) & 0.000 & 0.006 & 0.004 & 0.001 & 0.028 & 0.018 \\
\hline AR (2) (p value) & 0.013 & 0.267 & 0.354 & 0.652 & 0.071 & 0.104 \\
\hline
\end{tabular}

Note: $* \mathrm{p}<0.10 ; * * \mathrm{p}<0.05 ; * * * \mathrm{p}<0.01$. Robust $\mathrm{t}$ statistics in parentheses

Table 6 Stepwise regression using System GMM-two steps
(1)
(2)
(3)
(4)
(5)
(6)

Dependent variable: D.log housing price

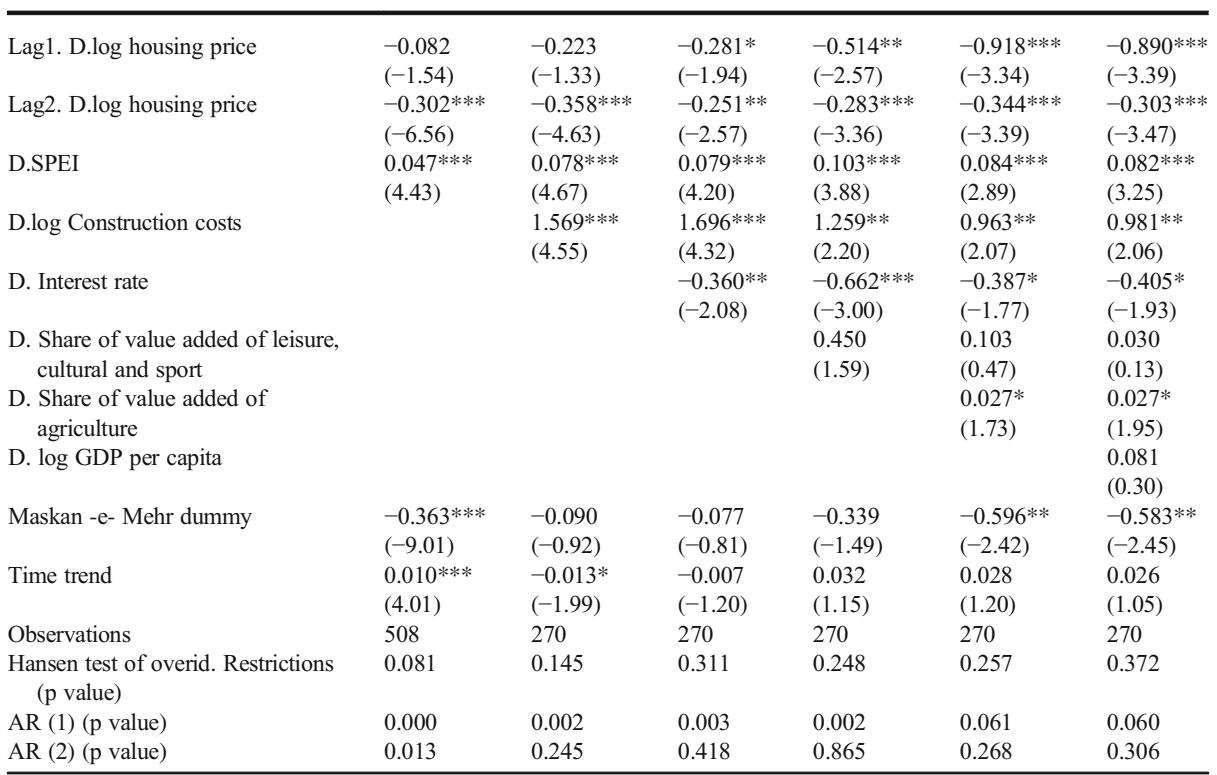

Note: $* \mathrm{p}<0.10 ; * * \mathrm{p}<0.05 ; * * * \mathrm{p}<0.01$. Robust $\mathrm{t}$ statistics in parentheses 
Table 7 Long difference (LD) estimations

(1)

S5. $\log$ housing price
LS5. $\log$ housing price

LS5. log GDP per capita

LS5. Interest rate

LS5. $\log$ Construction costs

LS5. SPEI

LS5. Share of value added of leisure, cultural and sport

LS5. Share of value added of agriculture

LS5. Maskan -e- Mehr dummy

LS5. Time trend

LS5. $\log$ land price

$\mathrm{N}$
$0.662 * * *$

(9.41)

$-0.077$

$(-1.34)$

0.091

(0.15)

-0.180 *

$(-1.71)$

$0.040 * *$

(2.13)

$-0.048$

$(-0.81)$

0.005

(1.29)

$-0.090$

$(-1.21)$

$-0.036 * * *$

$(-3.50)$

150
$-0.246$

$(-1.61)$

$-1.091$

$(-0.67)$

$-0.318$

$(-1.34)$

0.055

(1.41)

$-0.161$

$(-0.93)$

0.016 *

(2.03)

$-0.307$

(-1.64)

$-0.084 * * *$

$(-3.62)$

$0.448 * * *$

(4.73)

149

Note: $* \mathrm{p}<0.10$; ** $\mathrm{p}<0.05$; *** $\mathrm{p}<0.01$. Robust $\mathrm{t}$ statistics in parentheses. $\mathrm{S}$. and L. calculate seasonal differences and lagged seasonal differences and 5 refers to number of differencing length

Open Access This article is licensed under a Creative Commons Attribution 4.0 International License, which permits use, sharing, adaptation, distribution and reproduction in any medium or format, as long as you give appropriate credit to the original author(s) and the source, provide a link to the Creative Commons licence, and indicate if changes were made. The images or other third party material in this article are included in the article's Creative Commons licence, unless indicated otherwise in a credit line to the material. If material is not included in the article's Creative Commons licence and your intended use is not permitted by statutory regulation or exceeds the permitted use, you will need to obtain permission directly from the copyright holder. To view a copy of this licence, visit http://creativecommons.org/licenses/by/4.0/.

\section{References}

Abiodun BJ, Salami AT, Matthew OJ, Odedokun S (2013) Potential impacts of afforestation on climate change and extreme events in Nigeria. Clim Dyn 41:277-293

Adams Z, Füss R (2010) Macroeconomic determinants of international housing market. J Hous Econ 19:38-50

Alaedini P, Ashrafzadeh HR (2016) Iran's post-revolutionary social justice agenda and its outcomes: evolution and determinants of income distribution and middle class size. In: Farzanegan MR, Alaedini P (eds) Economic welfare and inequality in Iran: developments since revolution. Palgrave Macmillan, New York, pp $15-45$

Anwar NH, Sawas A, Mustafa D (2020) 'Without water, there is no life': negotiating everyday risks and gendered insecurities in Karachi's informal settlements. Urban Stud 57:1320-1337

Arellano M, Bover O (1995) Another look at the instrumental variables estimation of error components models. J Econ 68:29-51

Baltagi BH (2008) Econometric analysis of panel data, 4th edn. Wiley, Chichester

Baltagi BH, Demetriades PO, Law SH (2009) Financial development and openness: evidence from panel data. J Dev Econ 89:285-296 
Barbeta A, Ogaya R, Peñuelas J (2013) Dampening effects of long-term experimental drought on growth and mortality rates of a holm oak forest. Glob Chang Biol 19:3133-3144

Beguería S, Vicente-Serrano SM, Reig F, Latorre B (2014) Standardized precipitation evapotranspiration index (SPEI) revisited: parameter fitting, evapotranspiration models, tools, datasets and drought monitoring. Int J Climatol 34:3001-3023

Bernstein A, Gustafson MT, Lewis R (2019) Disaster on the horizon: the price effect of sea level rise. J Financ Econ 134:253-272

Bin O, Landry CE (2013) Changes in implicit flood risk premiums: empirical evidence from the housing market. J Environ Econ Manag 65:361-376

Birjandi MF, Yousefi K (2018) Dust emissions and manufacturing firm productivity: comprehensive evidence from Iran. Fifth International Conference on the Iranian Economy. Amsterdam, the Netherlands, March 8-9. Retrieved from: https://bit.ly/34wnnZY. Accessed 21 Dec 2020

Bjorvatn K, Farzanegan MR (2013) Demographic transition in resource rich countries: a bonus or a curse? World Dev 45:337-351

Blundell R, Bond S (1998) Initial conditions and moment restrictions in dynamic panel data models. J Econ 87: 115-143

Bunten D, Kahn ME (2014) The impact of emerging climate risks on urban real estate price dynamics. NBER working paper series, No. 20018. Retrieved from: http:/www.nber.org/papers/w20018.pdf. Accessed 21 Dec 2020

Butsic V, Hanak E, Valletta RG (2011) Climate change and housing prices: hedonic estimates for ski resorts in western North America. Land Econ 87:75-91

Cavin L, Mountford EP, Peterken GF, Jump AS (2013) Extreme drought alters competitive dominance within and between tree species in a mixed forest stand. Funct Ecol 27:1424-1435

Dehghanpisheh B (2018) Water crisis spurs protests in Iran. Reuters world news (29 march 2018): https://af. reuters.com/article/worldNews/idAFKBN1H51BL

DiPasquale D, Wheaton W (1992) The markets for real estate assets and space: a conceptual framework. Real Estate Econ 20:181-198

Eichholtz P, Steiner E, Yönder E (2018) No shelter from the storm: hurricanes and commercial real estate values. Available at https://ssrn.com/abstract $=3206257$

Eves C, Wilkinson S (2014) Assessing the immediate and short-term impact of flooding on residential property participant behaviour. Nat Hazards 71:1519-1536

Radio Farda (2018) Millions facing water shortages, Warns Energy Minister. Retrieved from https:/en. radiofarda.com/a/iran-water-shortage-drought/29186602.html

Farzanegan MR (2013) Effects of international financial and energy sanctions on Iran's informal economy. SAIS Rev Int Aff 33:13-36

Farzanegan MR, Gholipour HF (2016) Divorce and the cost of housing: evidence from Iran. Rev Econ Househ 14:1029-1054

Farzanegan MR, Hayo B (2019) Sanctions and the shadow economy: empirical evidence from Iranian provinces. Appl Econ Lett 26:501-505

Farzanegan MR, Gholipour HF, Nguyen J (2016a) Housing costs and inequality in post-revolutionary Iran. In: Farzanegan MR, Alaedini P (eds) Economic welfare and inequality in Iran: developments since revolution. Palgrave Macmillan, New York, pp 111-128

Farzanegan MR, Khabbazan M, Sadeghi H (2016b) Effects of oil sanctions on Iran's economy and household welfare: new evidence from a CGE model. In: Farzanegan MR, Alaedini P (eds) Economic welfare and inequality in Iran: developments since revolution. Palgrave Macmillan, New York, pp 185-211

Feizi M, Heidarzadeh Janatabadi N, Saradari Torshizi A (2019) Rainfall and social disputes in Iran. Water Policy 21:880-893

Galinato G, Tantihkarnchana P (2018) The amenity value of climate change across different regions in the United States. Appl Econ 50:4024-4039

Gholipour HF, Farzanegan MR (2015) Marriage crisis and housing costs: empirical evidence from provinces of Iran. J Policy Model 37:107-123

Gholipour HF, Lean HH (2017) Ripple effect in regional housing and land markets in Iran: implications for portfolio diversification. Int J Strateg Prop Manag 21:331-345

Glaeser EL, Gyourko J, Saiz A (2008) Housing supply and housing bubbles. J Urban Econ 64:198-217

Hahn J, Hausman J, Kuersteiner G (2007) Long difference instrumental variables estimation for dynamic panel models with fixed effects. J Econom 140:574-617

Hamilton JM (2007) Coastal landscape and the hedonic price of accommodation. Ecol Econ 62:594-602

Harrison DM, Smersh GT, Schwartz AL Jr (2001) Environmental determinants of housing prices: the impact of flood zone status. J Real Estate Res 21:3-20 
Hendy J. et al. (2018) Drought and climate change adaptation: impacts and projections. Economic and public policy research, Motu note no. 31, Wellington. Retrieved from: https://www.motu.nz/our-expertise/ environment-and-resources/climate-change-impacts/drought-and-climate-change-adaptation-impacts-andprojections/. Accessed 21 Dec 2020

Ho C, Hite D (2008) The benefit of environmental improvement in the southeastern United States: evidence from a simultaneous model of cancer mortality, toxic chemical releases and house values. Pap Reg Sci 87:589-605

Huang DJ, Leung CK, Qu B (2015) Do bank loans and local amenities explain Chinese urban house prices? China Econ Rev 34:19-38

Islamic Parliament Research Center of Iran (2017) Examining water crisis and its consequences in Iran. Islamic Consultative Assembly, Tehran. Available at: http://rc.majlis.ir/fa/report/show/1040201 (in Farsi, access 30.12. 2019)

Keivani R, Mattingly M, Majedi H (2008) Public management of urban land, enabling markets and low-income housing provision: the overlooked experience of Iran. Urban Stud 45:1825-1853

Lamond J, Proverbs D, Hammond F (2010) The impact of flooding on the price of residential property: a transactional analysis of UK market. Hous Stud 25:335-356

Mendelsohn R, William DN, Shaw D (1994) The impact of global warming on agriculture: a ricardian analysis. Am Econ Rev 84:753-771

Motasedi S, Khazaei Soltanabadi S, Etemad K, Rashidi Y, Gheybipour H, Rohani Rasaf M (2016) Evaluation of the association between air pollutants and number of cases with severe acute respiratory syndrome recorded at emergency medical centers in Tehran, Iran in 2013. J Health Res Community 2:38-44

Muellbauer J (2012) Housing and the macroeconomy. Elsevier Science, International Encyclopedia of Housing and Home, pp 301-314

Nickell SJ (1981) Biases in dynamic models with fixed effects. Econometrica 49:1417-1426

Oikarinen E, Bourassa SC, Hoesl M, Engblom J (2018) U.S. metropolitan house price dynamics. J Urban Econ 105:54-69

Ortega F, Tașpınar S (2018) Rising sea levels and sinking property values: hurricane Sandy and New York's housing market. J Urban Econ 106:81-100

Petkov I (2018) Weather shocks, house prices, and population: role of expectation revisions. MPRA paper no. 89805, https://papers.ssm.com/sol3/papers.cfm?abstract id=3156783

Polinsky AM, Rubinfeld DL (1977) Property values and the benefits of environmental improvements: theory and measurement. In: Wingo L, Evans A (eds) Public economics and the quality of life. Johns Hopkins Univ. Press, Baltimore, pp 154-180

Potop V, Možný M, Soukup J (2012) Drought at various time scales in the lowland regions and their impact on vegetable crops in the Czech Republic. Agric For Meteorol 156:121-133

Rajapaksa D, Zhu M, Lee B, Hoang V, Wilson C (2017) The impact of flood dynamics on property values. Land Use Policy 69:317-325

Roback J (1982) Wages, rents, and the quality of life. J Polit Econ 90:1257-1278

Salami H, Shahnooshi N, Thomson KJ (2009) The economic impacts of drought on the economy of Iran: an integration of linear programming and macroeconometric modelling approaches. Ecol Econ 68:1032-1039

Samarasinghe O, Sharp B (2010) Flood prone risk and amenity value: a spatial hedonic analysis. Aust J Agric Resour Econ 54:457-475

Schlenker W, Hanemann WM, Fisher AC (2005) Will U.S agriculture really benefit from global warming? Accounting for irrigation in the hedonic approach. Am Econ Rev 95:395-406

Shiva M, Molana H (2019) Climate change induced inter-province migration in Iran. AEA annual conference, Atlanta

Sodaei A (2015) Who grabs land in Iran? Available at: https://www.bbc.com/persian/business/2015/10/151010 145_iran_land_grabbing (in Farsi, accessed 27.6.2020)

Somorowska $U$ (2016) Changes in drought conditions in Poland over the past 60 years evaluated by the standardized precipitation-evapotranspiration index. Acta Geophysica 64:2530-2549

Speyrer JF, Ragas WR (1991) Housing prices and flood risk: an examination using spline regression. J Real Estate Financ Econ 4:395-407

Svoboda MD, Fuchs BA, Poulsen CC, Nothwehr JR (2015) The drought risk atlas: enhancing decision support for drought risk management in the United States. J Hydrol 526:274-286

Tajaddini R, Gholipour HF (2017) National culture and default on mortgages. Int Rev Financ 17:107-133

Tobin G, Newton T (1986) A theoretical framework of flood induced changes in urban land values. Water Resour Bull 22:67-71

Vicente-Serrano SM, Beguería S, López-Moreno JI (2010a) A multiscalar drought index sensitive to global warming: the standardized precipitation evapotranspiration index - SPEI. J Clim 23:1696-1718 
Vicente-Serrano SM, Beguería S, López-Moreno JI, Angulo M, El Kenawy A (2010b) A new global $0.5^{\circ}$ gridded dataset (1901-2006) of a multiscalar drought index: comparison with current drought index datasets base on the palmer drought severity index. J Hydrometeorol 11:1033-1043

Vicente-Serrano SM, Beguería S, Lorenzo-Lacruz J, Camarero JJ, López-Moreno JI, Azorin-Molina C, Revuelto J, Morán-Tejeda E, Sanchez-Lorenzo A (2012) Performance of drought indices for ecological, agricultural and hydrological applications. Earth Interact 16:1-27

World Bank (2016) High and dry: climate change, water, and the economy. The World Bank, Washington, DC

Yu M, Li G, Hayes MJ, Svoboda M, Heim RR (2014) Are droughts becoming more frequent or severe in China based on the standardized precipitation evapotranspiration index: 1951-2010? Int J Climatol 34:545-558

Yusuf AA, Resosudarmo BP (2009) Does clean air matter in developing countries' megacities? A hedonic price analysis of the Jakarta housing market, Indonesia. Ecol Econ 68:1398-1407

Zhai G, Fukuzono T, Ikeda S (2003) Effect of flooding on megalopolitan land price: a case study of the 2000 Tokai flood in Japan. J Nat Dis Sci 25:23-36

Publisher's Note Springer Nature remains neutral with regard to jurisdictional claims in published maps and institutional affiliations. 